Article

\title{
Butterfly Redreaming: Rethinking Free, with Zhuangzi Flying Westerly with Descartes, Lacan, Waldman...
}

\author{
Kyoo Lee \\ John Jay College, The City University of New York, New York, NY 10019, USA; \\ E-Mail: kylee@jjay.cuny.edu; Tel.: +1-212-237-8331 \\ Academic Editor: Krzysztof Ziarek
}

Received: 10 February 2015 / Accepted: 31 March 2015 / Published: 15 April 2015

\begin{abstract}
Usually, Zhuangzi's parable of "the butterfly dream/dreaming butterfly" is read as an enigmatic version, from "the East", of the Cartesian skeptical challenges to "objective reality" or else the Lacanian psycho-drama of the "pure gaze" in which "he", Zhuangzi, "is a butterfly for nobody", who stands for "the Real". Retooling some of the critical insights from these standard dialectical or anxiogenic approaches to this allegorical puzzle of self-identity, both of which, however, tend to leave unquestioned or else structurally overrate the binarized inner-exclusivity of typical pairs such as in/out, subject/object, illusion/reality, and all/nothing, this article proposes a relatively novel, fluid model of unraveling the speculative knot, the dots of lepidopterological spacetime irreducible to a simpler "point" in space and time. As we follow the narrative sequence more micro- and macrologically at once, with holistic, philopoetic attention to its intricate conceptual cues and contextual clues, especially its streaks and energies of "oppositional poetics" envisaged by Anne Waldman, for instance, we come to see more clearly the trans-categorical auto-generativity of its modal openness, its oddly powerful, non-militarily propelled, avant-garde peripherality. As Zhuangzi's butterfly gets freed this way from the discursive net where it is lost and found (often instantly dead), the vocalized figure of the "irritating" narrator, too, will change more freely, flying in and out and back in "daoistically" rather than agonistically.
\end{abstract}

Keywords: Zhuangzi; René Descartes; Jacques Lacan; Anne Waldman; dream; poetics; philopoetics; butterfly dream; freedom; Dao 
For Helen-Butterfly, who said she would come read Zhuangzi with me next time we could get together ${ }^{1}$

Once Zhuangzi dreamt he was a butterfly, a butterfly flitting and fluttering around, happy with himself and doing as he pleased. He didn't know he was Zhuangzi. Suddenly he woke up and there he was, solid and unmistakable Zhuangzi. But he didn't know if he was Zhuangzi who had dreamt he was a butterfly, or a butterfly dreaming he was Zhuangzi. Between Zhuangzi and a butterfly there must be some distinction! This is called the Transformation of Things [1,2] (Z 2:20, emphasis added).

\section{A Butterfly and a Child Thinking Inter Alia: "Once Zhuangzi Dreamt..."}

Many a reader will have at least passing familiarity with this parable of “butterfly dreaming” (夢蝶, mèngdié Z 2: 20) from Zhuangzi (莊子). The chiasmatic figure here of the butterfly-dreamer and/or the dreaming butterfly, in itself, also embodies the bohemian life and character of this ancient Daoist intellectual, Zhuangzi (莊子, 369-298 BCE) who, not unlike Diogenes of Sinope (412/404-323 BCE), stayed away from office politics, practically the office itself. This image of a butterfly dreamer/dreaming butterfly seems to capture rather perfectly Zhuangzi's free and freely recyclable spirit - a cocktail of aesthetic anarchism, ethical passivism, literary surrealism, philosophical relativism, poetic skepticism, political cynicism, metaphysical agnosticism, and so on, bordering on obscurantism or mysticism: Is that all? Is Zhuangzi an escapist? A hippie-happy idler (good for, if not nothing, at least some thing such as no-thing)?

I think not. Something else seems to be going on, somewhere else in this text, on this very site; something more, something different, even deviant or fugitive at times, but in any case, something more or less than a case encasable as such. Below, let me try to show what else I seem to see in this picture: how exactly is Zhuangzi or Zhuangzi (the text) free, and free from what exactly?

"Once, Zhuangzi (or Formerly, I, Zhuangzi) [3]...", the passage begins. Strictly speaking, we do not actually know who the narrator is or where he or she is, and such is and should be, as I will show, the starting point. Zhuangzi mentions Zhuangzi and Zhuangzi uses Zhuangzi. Here, this usual use-mention distinction, a foundational axiom or modal imperative in certain "analytic" camps of philosophy, is staged, performed, rather than simply observed or noted: The modal difference is playfully teased out, and Zhuangzi/Zhuangzi eased out, without being ignored. Is Zhuangzi here the former I or the present I, or both, or neither? The answer seems bloody unclear, especially as the text simply repeats the name "Zhuangzi" without identifying or equating it as an "I" anywhere in the paragraph. Here, hear what one totally exasperated philosopher has to say:

The story of Zhuangzi and the butterfly must be one of the best known anecdotes in the philosophical literature. It is also, for me at any rate, one of the most annoying: the kind of philosophical whimsy that irritates rather than illuminates. But as is so often the case, it is

\footnotetext{
1 This paper is dedicated to Helen Tartar.
} 
when we are walking away from philosophical problems that we realize that they point, however unsteadily, to something we cannot entirely dismiss [4].

Irritatingly illuminating: the question for me, for Raymond Tallis as well to a certain extent, becomes not so much whether to scratch the itch or walk away from it, as how to scratch it, how to walk with it, given that it $i s$ and is felt recurrently in the localized form of it be(com)ing itchy. As Sandra Wawrytko [5] observes: Zhuangzi-Butterfly, akin to Nietzsche-gadfly, is a kind of paralogical twin conjoined by the "both/and logic" that "deconstructs deconstruction", the negative streak of deconstruction in particular. Note again: to deconstruct deconstruction, not something constructed: What could this reflexive repetition mean? What that conjunction does topologically-topoanalytically or topoanalogically - in Zhuangzi's text is to play up material connectivity and associational continuity between beings while holding in view their mutual exclusivity, itself categorically maintained by the discursive differentiation of this-or-that, which is where "some distinction", that gestural division and eventual discernment, takes place. Zhuangzi-Butterfly covers - embraces - itself, its own contradictions acutely, as it hovers around.

The line of thinking Tallis pursues and draws typifies the "modern western philosophical", particularly "analytic", way of handling and controlling Zhuangzian self-differentiation, which remains, in my view, insufficiently analytic, although ten(ur)able. Shifting his focus to a more definitive if not defining or refined moment in this dream-thinking, Tallis privileges the independence of a perspective, an Archimedean standpoint. As he summates, just as a certain Descartes coming out of multiple Descartes would do when out to declare cogito sum: "The viewpoint is decisively his (Zhuangzi's), and there is an undeclared assumption that the story is being told from outside of the dream, and indeed outside both the sage's waking and dream states so that they can be compared and the pretense of equivalence teasingly advanced" [4]. Presumably then, as assumed, Zhuangzi becomes the "Cartesian" subject of reflection or at least a variant, e.g., one "pretending", "teasing", "advancing”, "playing along, knowingly"...who knows? Again, what's the point—of it all? How else can we hold the line before handling it? Or/and more basically, why bother at all?

Now I am looking at a point of divergent convergence, a web about to emerge. Here is how and where my thought parts from that philosopher's. I, too, see the important heuristic function of the Zhuangzian riddle. As Tallis puts it succinctly, "some kind of skepticism, justifying an inquiry that enables us to question the all-too-obvious, the glass wall of our everyday thinking about everyday life, seems entirely in order" [4]; again, as the parable ends with this resounding reminder, there must be "some distinction" between (two) things usually taken for granted as part of the same, e.g., the dreaming I and the wakeful I as belonging to the "I", in sum, of I think, I feel, I wonder, I imagine, etc. While Tallis and I share this big picture, i.e., the analogical point about the importance of critical philosophizing, a crucial detail in it also generates a bigger picture that we do not seem to share as readily: How should one read butterfly crossing, cruising even, within that very event of dreaming framed as such? Arriving? Leaving? Quivering? I am not going in or out anywhere, even with Zhuangzi-Butterfly, until and unless I can find a more satisfactory answer to that question. The point of fact I am focusing on is that the localized point of observation, articulated by Tallis on the discursive topos or perspectival fixity of Zhuangzi actually, immediately, unpredictably, almost totally, 
turns into something else: it is also a point of connection or transition including transformative transgression, as in a dot.

The usual, methodologically disembodied skepticism, characteristic of Descartes' hyperbolic doubt, enters a world of vitalist rationalism and transcorporeal materialism too, where a perspective itself, with its innate topological fluidity and porosity, would grow and move around, while itself forming, a sort of electromagnetic dot that potentializes and activates things, all sorts of things, everything in transit(ion) inside and outside what we call or end up calling the world. What I have in mind, drawing in part on the life of René Descartes, the famous sleepyhead, along with my own life-long expertise as a never-an-A pupil, is something like the inner Descartes in all thinking things, the transitional child in bed, about to fall asleep or unready to get up, staring at some wallpaper patterns in the favorite corner or middle of the ceiling above, doing (her own) math in her head, dotting here and there in her world across her headspace, sometimes thinking something else, transported elsewhere [6]. The trick seems to be how to break open, while sheltering, those layers and glass walls of thinking, thinking that occurs without evidentiary traces or preset trajectories - a life and afterlife of serial (mental) defenestration.

Note the threshold, the discursive code switch or, say, swerve, a sweeping or sliding move from Zhuangzi to Butterfly and vice versa, rather than just Zhuangzi 1 to Zhuangzi 2 or Zhuangzi 0, flattened and chopped up and processed with nothing boring or even exciting in between. In the Euclidean geometrical script almost automatically followed and fortified by disciplined thinkers such as Tallis who is advancing it, the solar circular irreducibility of the Cartesian presence of the reflective $\mathrm{I}$ is at once established and premised upon an anchored gaze "outside" the speculative muddle in the middle which, in my view, is what Zhuangzi 0 would be like: neither some white vessel nor a black hole but something composite, a dense, gray, gooey matter that trembles; this seems also how the brain-in-a-vat skeptics can be liberated from - survive - their own speculative swamp or abyss, their empty nest or vest. I am reminded of the middle of/muddle in "a house besieged," as writer Lydia Davis envisages it:

In a house besieged lived a man and a woman. From where they cowered in the kitchen the man and woman heard small explosions. "The wind", said the woman. "Hunters", said the man. "The rain", said the woman. "The army", said the man. The woman wanted to go home, but she was already home, there in the middle of the country in a house besieged [7].

The (muddled) middle being where things overlap while separated, such as a wall or a threshold between 11:59 and midnight, it or "it" becomes a portable allegory of life in itself; "man's life has always been a muddle like this. How could I be the only muddled one, and other men not muddled?" (Z 2: 3). That much seems clear, breathtakingly simple, however surreal-also to Zhuangzi. Then again, one wonders: Who is (the) one outside "a"/the/this/that "house besieged"?

The subject returns - to the scene. Sure, when she wants to go home, she wants to go home: simple as that, we get that. Yet again, along the way, we still need to try and figure out where that "home" is and who that is: not just the zero-point of thinking, but more closely, incisively, a zero-degree thinking, writing, reading...living...zero itself in transit.

Recall the bifocality of the opening call, "Once Zhuangzi dreamt (Formerly, I, Zhuangzi ...)", while attending, this time, to the contextual temporality of the inaugural sequence: it seems equally unclear how that "decision" (of who is in or out, narrating this allegory), not to mention intention, could be set by Tallis or Zhuangzi himself or anyone else; where the agent is or what the goal is, one has little idea. 
If Zhuangzi is speaking of himself who is also Zhuangzi, given the very possibility of the former Zhuangzi being a butterfly dreaming of Zhuangzi, as the tale goes, the identity, ontological or otherwise, of the present Zhuangzi cannot be established as such, either. If anything, the least we could say might come down to this, last one perhaps: Zhuangzi or the storytelling butterfly, the double switchboard operator, is passing by as a dis/identity marker without showing himself or itself per se.

As Hans-Georg Moeller notes:

The non-present narrator of the story neglects neither being awake nor dreaming, neither life nor death. To him, all present segments are equally valid and authentic. Even if he no longer identifies himself with any particular segment, this is by no means negated or falsified by non-presence: on the contrary, it is balanced or held up by non-present. So just as the narrator does not deny or falsify the validity of a Zhuang Zhou or the butterfly, Daoist non-presence does not deny or falsify the validity of the present. In this sense, Daoism does not "relativize" (as it is sometimes proposed) the validity of present forms of being: the sage, while being non-present, rather affirms the realm or process of present with all its equal but distinct segments ([8], p. 445).

"Held up by non-present", "the non-present narrator" too becomes at every turn an ellipsis, a set of dots generating its own connective tissues each time. Quite simply, as folk wisdom would have it, shifting a perspective and expanding a horizon ever so slightly at times of crisis could free one, big time; connect this dot to another, or redraw the line in a different way, instead of treating each point or position as fixed, immobile, and autonomous, as some real estates of the ego. Move and move to a point you yourself could make, push open, even a tiny bit, but again in any case, holistically each time. If Zhuangzi's Daoism does not "relativize" ontological or epistemological measures, what it does is to relate, to re-relate, making things count, everything, every single little thing, relevant to one another. What we learn and hear from this iconic Zhuangzi-Butterfly that also still profoundly chimes with the ethico-performative way-making tradition of Daoism, as Kai-Yuan Cheng stresses, is how to "relate" relationally, not just relatively or relativistically; "free association" through "leisurely wandering" (Z 1) becomes ontological, existential, and environmental, not just social, semantic, or mental.

Take time. It takes time to see such lively-deadly differences emerging from a matrix of things, however minimal or insignificant or contingent or accidental or subtle or ethereal — all equally real at any rate, in the eyes of Zhuangzi-Butterfly. Often, departing from today that was tomorrow, one's worldview changes, subtly or drastically, which would amount to the same. Self-differentiation becomes ordinary, expected at times. It is as if some space in the self, usually locked in, would get "freed" up as time goes by; or maybe selfhood, too, flies - somehow, somewhere-with time. How freely does one change, getting "transformed"? Again, Zhuangzi-Butterfly holds the key without holding onto it, so to speak. And how would that Mobius pair free one: you and me, us, them?

Before we get (to) freedom, I want to spend some more time trying to figure out what cements a point and a dot in the first place. We need to free up, to defragment, that field of elasticity before we can complete the paradigmatic conversion or translation between the two. In other words, what else is a dream-thought that lasts? How else does thinking release, disperse, give up, or randomize its own-ness without losing its plot or steam or stream? Where does the cogito find its bedfellow(s) or incubator(s)? 


\section{A Child and a Puppet Reading inter alia: "He was a Butterfly"}

Read what Jacques Lacan says about dreaming as reading: "In dreams, for example, we are quite capable of having the feeling of reading something, whereas, obviously, we can't claim that there is any correspondence with a signifier" (emphasis added) [9]. Dreaming is feeling; it feels like reading, with the active-passive-aggressive-dormant dreamer-reader-watcher(s) inside/outside the cinematic frame as the scenes roll by. Like a reader bolted to a text that unfolds toward and "refolds" its own cliff at every turn [10], the dreamer in a dream would sometimes face the death of the dreamer herself or a fatal crash that seems to crush everything, everyone, every one of us transported into \& out of that dreamscape including nightmares.

All that is far from "free", some might say. Right. Every now and then, dreamwork offers or propels some temporary madness, a psychic relief of and from altered realities, sweet or sweaty or mixed as in mixed feelings - especially if we, everyday Cartesian-Zhuangzian sleeper-dreamers, can say "upon waking" that, well, there must be "some distinction", however elusive or effusive, some-thing or one other than just me in me. Right there, this time, with Lacan reading his way through Daniel Paul Schreber's (1842-1911) memoir, with some "Secretaries to the Insane," the title of his Seminar XVI (1956) on the schizophrenic "little man", we catch a glimpse across the persistent polarity of the life of "ego", ironically stabilized by the "secretary" who reads, who is not exactly the same as the Hegelian slave who, in any ideally revolutionary historical context, would eventually become the master, or at least work with a view to becoming that. Rather, in Lacanian terms, this abyssal power differential between the unreadable boss and the studious secretary reflects the disjunctively functional or, creatively messed-up/mixed-in, sexy/sexuated/sexualized [11] relationship between "the Other," the symbolic, unidentifiable-fied X, and "the other," the imaginary this or that mis/identified-able as such:

We get the impression that it's insofar as he hasn't acquired or has lost this Other that he encounters the purely imaginary other, the fallen and meager other with whom he is not able to have any relations except relations of frustration - this other negates him, literally kills him. This other is that which is most radical in imaginary alienation.

Now, this capture by the double is correlative of the appearance of what can be called the permanent discourse that underlies the inscription of what takes place over the course of the subject's history and doubles all his acts. It isn't impossible, moreover, to see the discourse emerge in a normal subject ([9], p. 209).

The invisibly operative, symbolic, anxiogenic "father" of the everyday little man is, again for Lacan, the functionary generator of schizophrenia, mundane or murderous, and the distinction itself, while there, becomes obscure due to its hyper-normal near-universality and permanence. The structural reach and force of these "double" discourses or layers or standards of the other vis-à-vis Other as well as the other/Other vis-à-vis one, constitutive of the phenomenal realities of the ego thus dictated and performed, is illustrated in this well-known passage, where Lacan theorizes the other/Other in straightforward terms, drawing derivatively/deviantly on the Hegelian idioms of dialectical reciprocity:

Who normally speaks in reality, for us? Is it reality, exactly, when someone speaks to us?

The point of the remarks I made to you last time on the other and the Other, the other with 
a small o and the Other with a big $\mathrm{O}$, was to get you to notice that when the Other with a big $\mathrm{O}$ speaks it is not purely and simply the reality in front of you, namely the individual who is holding forth. The Other is beyond that reality.

In true speech the Other is that before which you make yourself recognized. But you can make yourself recognized by it only because it is recognized first... This supplementary dimension - the reciprocity - is necessary for there to be any value in this speech...You are my master or You are my woman...It is through recognizing it that you institute it, and not as a pure and simple element of reality, a pawn, a puppet, but an irreducible absolute, on whose existence as subject the very value of the speech in which you get yourself recognized depends. Something gets born there.

In other words, wherever a puppet talks it's not the puppet that talks, but it's someone behind it [12].

Digressing further, am I? What happened to that ancient idea of "freedom," with which we started our mini-journey? What has Zhuangzi's butterfly, an emblem of Daoist freedom, to do with Lacan's puppet, a figure of psychoanalytic subjection and, further back, dreaming as reading?

The butterfly is linkable, though not equatable, to that "irreducible absolute", the puppet master, the radical, necessary fiction in the specular and speculative world of Lacanian parallelism and allegorical paternalism, where ultimately "the Father" rules, justly or not. The genius of Lacan's model, the kind of psychoanalytic dynamism harder to detect in Tallis's more reductive analysis or the Hegelian-Marxist traditions of dialectical thinking broadly conceived, is in its structural double reading, pattern-recognition, of a certain micro- and macroscopic traffic, asymmetrical reciprocity, between one and the other, or the other and the Other: Lacan makes the two relate to each other by bringing the "outside" gaze in, by drawing the Other "beyond" or "behind" or "before" "(that) reality" into the semiologico-scopic field, by having it first activated, mobilized, by the puppet-like other even when the Master Other is, inevitably, withdrawing to its own heart of privileged darkness, the unreadable.

And then there seems another sort of other/Other, which Lacan's post-Hegelian other or Other does not seem to catch entirely or care about much. Here, I do not mean to evoke some overcapitalized rhetoric of East-West untranslatability or universalized transcendental or cosmic ineffability. Rather, the other sense of the other rising here I am trying to raise my consciousness to is conceptual, transhistorical, almost transtemporal: if the fly is not quite the other or Other or even the one to catch, but rather one among many, "ten thousand", as the classical Chinese idiom would go, I am interested to follow the movements of that other-not $U r$ and the Über-butterfly or puppet that stops or stabilizes the infinite regressing of buttery flying and puppeteering itself, again, in a way not resorting to a dialecticized absolutism or ontological monism. Where would its discontinuous identities unfurl or coagulate, or how would one spot it among 10,000 singular-plurals?

Lodged in the proto-Cartesian-Lacanian thinking thing (res cogitans) that is something other than other or Other, with the two still held apart distinctly if not clearly, is a flying allegorical "sobject...a perpetual procedural loop" or "substantive eclipse" of subjectivity and objectivity [13]; as seen earlier, it is found trapped (sort of) alive in the child lying in bed, that coffin simulator, daydreaming, virtually somnambulating, sometimes sobbing over what happened, what matters, fantasizing at times about what might be coming or not. Through such a figure moved to think as if for the first time, I should 
like to repeat this dream question just once more: what is it that connects and disconnects Zhuangzi's butterfly and Lacan's puppet? What makes them associate or dissociate? What catalyzes, not just analyzes, their association and dissociation? What is one, this third one, that runs, races, rushes through the two? How to dot spacetime freely, infinitely, alternatively, singularly, anew, as if for the first time in the childhood of the mindbody: that is the question I continue to follow in what follows.

\section{Living through Butterfly Awakening, Spacing: "A Butterfly Fluttering about, Happy..."}

There is a path in an empty space as well. That is where Butterflies fly along. It is called a butterfly route. As long as you are equipped with wings, you can use it. Bypassing a two-dimensional world, you go three-dimensional [14].

The butterfly \& the flower are not a duo, and life-death \& dream not apart [15].

What does a butterfly do? It flies... and what follows? Its “fluttering about” (栩栩, xǔxǔ) creates its own fore/backgrounds and nominal traces (Z 1:6) along the way; its "butterfly route" (蝶道 dié dào) — not just an effect—like its dao (way, path, route, track, method, technique), unfolds like a cat's cradle gone wilder, frameless, viral. To think of, while away, a-way, with a butterfly flying away along its own silky dreamy route, is to think-go vectorial, manifold; to track and crack the cross-sectional, soft disjunctivity of its transitory appearance as well as disappearance.

Following a butterfly around, while backtracking some fortuitous itinerary of the butterfly crossing itself, one gets closer to a vital matter — of life and death — that auto-creates flight paths. As trivial as it may sound, truly enough, anything - any thing, body, one - that moves makes its own way in or out, in and out, auto-spacing, interacting with the environment it engages, all then subject to the laws of transformation. When pipe-dreamers and armchair adventurers, fighting a battle in a teacup, think and talk of a butterfly in some imaginary glassy box, of and through which Zhuangzi, too, speaks with the allegorical concision of a hermit warrior, one (especially philosophers including failed poets) should try to re-member the double seminal productivity of all the (hidden, obvious, cosmic, and cosmetic) details: the sky in the background [16], for instance, to begin with. In other words, as the "flight of the butterflies is governed by 'the conspiring elements - winds and scents, foliage and sun' (SW III, 350)...the elements come together through some secret plan, of which the butterfly becomes the image" [17]; it is no longer then a secret that there is also the wind that takes it, not to mention the window through which to view, which will frame the dust in the wind taking us to "the fog" [18] above a lake that would unfold around the corner of some California "highway" [19], with fellow microbes in the field, on board.

Follow, also, the dots in the night sky that "connects the heaven and the earth" [20], a universe in a university folded in one of those stars...for indeed, again, to begin with: "There is a series of rooms. Each room frames a table, a book and an opening to the outside - an aperture of some sort" [21] inhabited also by the "wide slumbering lepidopterists" [22] who would or will have at least once thought twice that "so we dream the same (left page) do we dream the same (right page)" [22] in their "festive dreams" [23], those dreams dreamt in a Cartesian-Bachelardian [24]-Lacanian corner room, in the curvature of our embodied or ensouled existence, where beings sprout, moving about with the relative ease and itemized vitality of "the little child just sitting in the snow" [25], the child so carefree 
as not to appear to be even wishing or intending to be free, no matter what, no matter whatever sort of other/Other is out there or in here. So what I am dreaming thereof with philopoet children are, just to list the first two for now: Christmas every other day so that we can remember to look forward to it, and, if possible, wanjun-byuntae (a complete metamorphosis/total perversion, 완전변태, 完全變態, a polysemic Sino-Korean interlingual pun in Korean, the title of Oisoo Lee's fiction cited above).

The intertextual portability as well as universal probability of Zhuangzian performative irony and its sobering twists and turns remain potent this way, more vibrant, extensive, intriguing, unwieldy than the usual, neat ("Oriental" or "Eastern") package it comes in. To repeat: the dreaming butterfly would and should not care about "me" or "you", but, more simply, mind her own business or dreams, doing her own thing every time she flies or not. See, "though the cook may not run his kitchen properly, the priest and the impersonator of the dead at the sacrifice do not leap over the wine casks and sacrificial stands and go take his place" (Z 1:7): This Zhuangzian version of 'minding one's own business' also illustrates an art of active inaction (無爲, wuwei) that respects material tautology, leaving the done done, undone undone, dead dead; of associating beings with beings or non-beings without forcing them into the boxy geometry of a relationship per se. To wit: just know that a butterfly flies when it does.

Turning "back to the things themselves" or themself, the phenomenal singularities of each and every $(10,000)$ thing, I am interested to think further via Zhuangzi-Butterfly itself and the dotted singularities of its movements: how to register its near-literal, irreducibly allegorical materialities, not just its analogical values or discursive functions; how to unpack that autopoetic space or aviational void repeatedly, every time differently; how to follow its living logic, its vital-viral forces carried in the butterfly zone, including the body so transportable and transported.

Again, we start with the arguably simplest fact that the butterfly flies in and out, and away, and at the end of the day, it is and no longer is a flying object, a body. We could replace it with "the short-lived cicada" that "does not know (what takes place between) the spring and autumn" (Z 1:4), or replace the cicada with you, and me, who do not know what takes place between today and tomorrow. Butterflies "R" Us, perhaps. In this scene of elastic fugitivity and layered vectoriality, the thinker, the self-reading sobject thingy, becomes like Walter Benjamin's "untidy (animal-scientist) child (my insertion)" in Berlin chasing around a butterfly, a child whose "life is like a dream", who would also capture and miss X, just standing there, staring into the void, mini-petrified by what (could not have) happened [26]. Here lies an allegory of cutting-edge thinking, a dialectical image of associative death about to enter nature or nature about to escape capture:

In a dream, he is a butterfly. What does this mean? It means that he sees the butterfly in his reality as gaze. What are so many figures, so many shapes, so many colors, if not this gratuitous showing, in which is marked for us the primal nature of the essence of the gaze. ...He is a captive butterfly, but captured by nothing, for, in the dream, he is a butterfly for nobody. It is when he is awake that he is Choang-tsu for others, and is caught in their butterfly net [27].

Thus spake Lacan, who sees nobody around that butterfly, all those other invisible bodies, an-other 10,000 folded into the background (gaze) of the Lacanian square, square root zero. Where is the body in all these? Gone where? The child in the snow wonders, bringing out her foldable bed from her backpack, ready to wander with Alice. So, Uncle Jacques, I too see the trouble, possibly half-yours. 


\section{A Philopoetics of Butterfly Redreaming: "Called a Transformation of Things"}

I am not thinking of Death, but Death is thinking of me.

He leans back in his chair, rubs his hands, strokes

His beard and says, "I'm thinking of Strand, I'm thinking

That one of these days I'll be out back, swinging my scythe

Or holding my hourglass up to the moon, and Strand will appear

In a jacket and tie, and together under the boulevards'

Leafless trees we'll stroll into the city of souls. And when

We get to the Great Piazza with its marble mansions, the crowd

That had been waiting there will welcome us with delirious cries,

And their tears, turned hard and cold as glass from having been

Held back so long, will fall, and clatter on the stones below.

$\mathrm{O}$ let it be soon. Let it be soon.

Reenter a butterfly dreamscape, through a nightmare if unavoidable, and, whatever the case, reclaim the present by re-dreaming as necessary - by reading one by one, step by step, nice and slow, fast to the core, skimming, not just scanning, words from the surface of self-liquidating realities, traces called history or story or so-called theory whose pretension is an intention to be outside history or story [29].

"How do we now navigate a new chaos of possibility?" [30]: Not just a possibility but more precisely a chaos of, the visionary poet Anne Waldman asks. As with Alice in Wonderland, whose boredom is a protest of this uninteresting being against that being engaged otherwise, this sort of perpetualized struggle for and against becoming-otherwise, namely the tactical self-retardation or acceleration of a wonder-wanderer à la Zhuangzi, might just be what we need at this point, or perhaps all we could do minimally. To paraphrase Waldman's millennial call for a sort of philopoetic activism in the age of post-Cartesian techno-commodification of self(ie)hood, the question is not exactly how to rebuild the think/dream-work/sleep-live/die-on/off modern binary super-machine now almost exhausted by self-consuming postmodernist discourses, but rather how to keep the dreamer awake or keep the awake dreaming more simply, organically, freely, especially among all this often suffocating "i-(mediated-small-but-fancy)-stuff" in the sprawling "Internet of things" nowadays, part of "Indra's net" of the empty universe as rooted and distant as Mahayana Buddhism of the third century. Save the philo-poet and the poet philosopher in our midst, who are nodding off with us, breathing with us in the 24/7 fresh air of capitalist somnambulism. Turning to this "buttery", netty, tricky part(ner) of "me", me that might become clearer when data-mined and qualified by quantity, I read on:

remember: no rules.

Poetry keeps changing its stress

and we might live more in our

dreams than in this dangerous

walking life, or not [31].

"No, never sleep" [30], whether in that sweet dream or in this dreadful diary, as the coupled distinction itself becomes increasingly unclear. Instead, keep the other eye half open/closed across time 
during this life-death moment at which sleeping, dreaming, thinking, reading, writing are all one of many things one does in tune with the performative tautology of spacetime weaving its way into and out of itself - as if awake all the time, even or especially while asleep. "You must go against the grain for the benefit of others. As the Muse said to Hilda Doolittle, 'Write. Write or die'." [30]—also meaning, Write and Die? As in, write when you write, "die when you die" [32], yes?

So be "rattled" [33], says a poet, not settled, in this long dream redreamt every now and then; have the bowl of your mind turned inside out, upside down, recall the tremor, the clamor, tiny or slippery, it does not matter, and even better. Such a poetical gesture of otherworldly worldly vigil, rhyming with phenomenological awakening, an almost spiritual alternative to "planetary finitude" [30], epochal closures, world-historical complacencies and conflicts and calamities would keep nourished and energized the extra-horizonal other, the sort of third other, to be sheltered with uncountable oddballs and queer fugitives often counted on by countless unpaired alter egos and organisms of the universe. This sort of "oppositional poetics," which Waldman dares to name with unfussy clarity, is what keeps the - or at least this - philosopher going, although relatively gingerly. Read on, thinkingly, as long as the interval allows - and pass it onto unknown and unknowing others as freely, givingly, as possible.

\section{Back to Conclusions}

"It"? I am dreaming a dream, thinking a thought of lateral, incisively inclusionary, middle-covering, muddle-exposing thinking across and among multitudes, planes, categories, boundaries, horizons; I am entertaining a proto-phenomenological vision of the infinite tapestry of oneness and openness, both cogitational and ontological.

So in short, here we are, I have come to see and am trying to show in "sum" ways Zhuangzi's parable of "the butterfly dream/dreaming butterfly" from a richer, onto-phenomenologically relational and materialist perspective; again in "sum" ways, we already know fairly well its rhetorical exemplarity as an example of the Cartesian skeptical challenges to "objective reality" or the Lacanian psycho-drama of the "pure gaze" in which "he", Zhuangzi, "is a butterfly for nobody", who stands for "the Real". Both frames, while helpful as scaffolds, as I highlighted above, tend to leave unquestioned or else structurally overrate the binarized inner-exclusivity of typical pairs such as in/out, subject/object, illusion/reality, and all/nothing. Instead, my line of reading explores a relatively novel, fluid model of unraveling the speculative knot, the "dots" of lepidopterological spacetime irreducible to a simpler "point" in space and time. As we follow the narrative sequence more micro- and macrologically at once, with holistic, philopoetic attention to its intricate conceptual cues and contextual clues, especially its streaks and energies of "oppositional poetics" envisaged by Anne Waldman, for instance, we come to see more clearly the trans-categorical auto-generativity of its modal openness, its oddly powerful, non-militarily propelled, avant-garde peripherality. As Zhuangzi's butterfly gets freed this way from the discursive net where it is lost and found (often instantly dead), the vocalized figure of the "irritating" narrator, too, will change more freely, flying in and out and back in "daoistically" rather than agonistically.

Such an idea of, say, an idea itself immediately becoming something else is embryonically allegorized by the big flying fish with which Zhuangzi (Z 1:1) famously opens. From the start of this journey into Zhuangzi's philopoetics of freedom, we have been accompanied and (mis)guided by that 
magical and mysteriously approachable figure of transformative immanence and immanent transcendence; it is also immediately ridiculed and envied, both rightly, by a cicada and a dove, for being uselessly expansive and carefree. Those hard-nosed, sneering pragmatists that would counterbalance the perils of lofty idealism with the perks of actual frequent flying are onto something, indeed. Especially good at math, these bite-size, down-to-earth, hard-working creatures cheerfully volunteer to prove, once and for all, the absurd futility of the very existence of the other, bigger fish-bird, which reminds me of those Mandarin metaphysicians from whom Descartes, too, tried to stay away. Jolly good. Fair enough.

Now, turn to this other, next issue:

The mushroom of a morning does not know (what takes place between) the beginning and end of a month; the short-lived cicada does not know (what takes place between) the spring and autumn. These are instances of a short term of life. (Z 2:2).

The joint, hinge, interstice, between and within bodies, individual or collective, nano or jumbo, here and there, neither "short" in itself nor "long" in itself but fitting itself anyway, is where transformative changes take place and are rendered visible retrospectively. Who, what, can "carry" such? Again, a change itself in the middle-muddle.

Given here is a multifaceted embodiment of the very force of oppositional philopoetics, in itself faceless, the third perspective or voice that keeps the other two in check, alive. What remains as a generative puzzle or a pressure-point in "enquiring minds" - as Zhuangzi signals with a cinematic, opening description (Z 2:1) of Nanguo Ziqi's peculiar posture "today", right there, right now-is precisely the transitory (non-)identity or transitional (dis)continuity: what is it that connects, i.e., perceptually differentiates while accommodating, the body of one, this one, Nanguo Ziqi, that happens to "look up to Heaven and breathe gently as if in trance... while leaning forward on the stool...like a withered tree" this way, and the body of the putatively same one, Nanguo Ziqi, that has not done or has not been seen to be doing that before. The narrative gaze has been there, which, again, does not necessarily mean that it remains self-identical.

Now surely, a cicada, our ancient Chinese pragmatist, would still have to make some noise: just what message could we take home? Why bother with this confusion, especially at the conclusion? When I cannot really know if I am "waiting for the scales of a snake or the wings of a cicada" ( $Z$ 2:13), what good is that suspense? At this stage of double-scaled reading as layered-suspended thinking, in this split scene of co-agitation twinly supported by the epistemo-phenomenology of not-so-knowing-and-knowing-so, I also see a smoke of imagination rising, out of the blue, from the Waldman-esque-Margrittean transgenic "dream images such as my shoulder being opened like a lid" [34], freeing the dead from my heart, "shoulder to shoulder" [35], welcoming a life through another channel...as "I", Celan, "an eye similar to yours on each finger, probe for a place, through which I can wake myself toward you, the bright hungercandle in mouth" [36], writing a line or two - to you, to go on.

\section{Conflicts of Interest}

The author declares no conflict of interest. 


\section{References and Notes}

1. Burton Watson. Zhuangzi: Basic Writings. New York: Columbia University Press, 2003. I am Using Burton Watson's Translation of Zhuangzi (莊子) with Minimal Modifications, Mostly Typographical or Stylistic.

2. The original Chinese text I am referring to is the standard edition. Chinese Text Project. “莊子—Zhuangzi.” Available online: http://ctext.org/zhuangzi (accessed on 1 February 2015). (Z 2:20) denotes (Zhuangzi, Chapter 2: Paragraph 20).

3. Chinese Text Project. “齊物論—The Adjustment of Controversies." Available online: http://ctext.org/zhuangzi/adjustment-of-controversies (accessed on 1 February 2015).

4. Raymond Tallis. "Zhuangzi and That Bloody Butterfly." Philosophy Now, February/March 2015. Available online: https://philosophynow.org/issues/76/Zhuangzi_And_That_Bloody_Butterfly (accessed on 1 February 2015).

5. Sandra Wawrythko. "Deconstructing Deconstruction: Zhuang Zi as Butterfly, Nietzsche as Gadfly." Philosophy East and West 58 (2008): 524-51.

6. I thank Mei-mei Berssenbrugge for inspiring me to open up my own text this way by encouraging me to document such a seemingly insignificant experience that, none the less, remains, as I do realize upon reflection, persistent like a breathing habit or pattern.

7. Lydia Davis. "In a House Besieged." In The Collected Stories of Lydia Davis. New York: Farrar, Straus and Giroux, 2009, p. 64.

8. Hans-Georg Möller. “Zhuangzi's 'Dream of the Butterfly': A Daoist Interpretation.” Philosophy East and West 49 (1999): 439-50.

9. Jacques Lacan. "Secretaries to the Insane." In The Psychoses. New York: W. W. Norton \& Company, 1997, p. 207.

10. Jean-Luc Nancy. On the Commerce of Thinking. New York: Fordham University Press, 2009, p. 21. I thank Helen Tartar, a reader par excellence, for an extensive and illuminating discussion of this point, which has become poignant with her tragic death in a car accident.

11. Lauren Berlant, and Lee Edelman. Sex, or the Unbearable. Durham: Duke University Press, 2013.

12. Jacques Lacan. "I've just been to the butcher's." In The Psychoses. New York: W. W. Norton \& Company, 1997, pp. 50-51.

13. Robert Fitterman, and Vanessa Place. Notes on Conceptualisms. New York: Ugly Ducklings, 2009, p. 40.

14. Oisoo Lee. Complete Metamorphoses/Perversion. Seoul: Haenaem Publishing, 2014.

15. Oisoo Lee. "Butterfly." In A Dictionary of Sensibility. Seoul: Dongsoongdong, 2006, p. 143.

16. I owe this point to poet Edwin Torres.

17. Eli Friedlander. Walter Benjamin: A Philosophical Portrait. Boston: Harvard University Press, 2012, p. 106.

18. Mei-mei Berssenbrugge. "Fog." In I Love Artists: New and Selected Poems. Los Angeles: University of California Press, 2006, p. 38.

19. Laura Mullen. "Ghost Mist" (summer 2006 pacific coast highway)." In Dark Archive. Los Angeles: University of California Press, 2011, p. 126.

20. Mei-mei Berssenbrugge. Reading, The Poetry Project. New York: St. Mark's Church, 2015. 
21. Lisa Robertson. Thinking Space. New York: Ellipse, 2013, p. 1.

22. Angela Rawlings. Wide Slumber for Lepidopterists. Ontario: Coach House Books, 2006. I thank Dee Morris for this reference.

23. Bruce Andrews, and Sally Silvers. New Year's Reading, The Poetry Project. New York: St. Mark's Church, 2015.

24. Gaston Bachelard. The Poetics of Space. Boston: Beacon Press, 1994.

25. Agnes Martin. "The Untroubled Mind." In Schriften. Edited by Dieter Schwarz. Ann Arbor: University of Michigan, Distributed Art Pub Incorporated, 2005, p. 35.

26. Walter Benjamin. One-Way Street and Other Writings. Translated By Edmund Jephcott and Kingsley Shorter. London: NLB, 1979, p. 73.

27. Jacques Lacan. "The Split between the Eye and the Gaze." In The Four Fundamental Concepts of Psycho-Analysis. New York: W. W. Norton \& Company, 1998, pp. 75-76.

28. Mark Strand. "2002." In Man and Camel. New York: Knopf Doubleday Publishing Group, 2008, p. 7.

29. M. NourbeSe Philip. Zong! Middletown: Wesleyan University Press, 2008.

30. Anne Waldman. "Oppositional Poetics." In Vow to Poetry: Essays, Interviews \& Manifestos. Ann Arbor: Coffee House Press, 2001, p. 51.

31. Anne Waldman. Makeup on Empty Space. Iowa: Toothpaste Press, 1984, pp. 25-26.

32. Allen Ginsberg, and Michael McClure. 'Reading, featuring Ginsberg songs 'Guru Blues,' and 'Gospel Noble Truths'.” Available online: https://archive.org/details/76P108 (accessed on 1 February 2015).

33. Mark Strand. "Sleeping with One Eye Open." In New Selected Poems. New York: Knopf Doubleday Publishing Group, 2009, p. xiii.

34. Anne Waldman. "Vow to Poetry: Anne Waldman Interview." In Disembodied Poetics. Edited by Anne Waldman and Andrew Schelling. Albuquerque: University of New Mexico Press, 1994, p. 46.

35. Paul Celan. "You May." In Breathturn into Timstead: The Collected Later Poetry. Translated by Pierre Joris. New York: Macmillan, 2014, p. 2.

36. Paul Celan. "The Undreamt." In Breathturn into Timstead: The Collected Later Poetry. Translated by Pierre Joris. New York: Macmillan, 2014, p. 2.

(C) 2015 by the author; licensee MDPI, Basel, Switzerland. This article is an open access article distributed under the terms and conditions of the Creative Commons Attribution license (http://creativecommons.org/licenses/by/4.0/). 